\title{
IMPLEMENTASI UNDANG - UNDANG NOMOR 32 TAHUN 2009 PADA PENGAWASAN PENAATAN PERIZINAN LINGKUNGAN HIDUP DI SALAH SATU PERUSAHAAN TAMBANG BIJIH NIKEL DI KABUPATEN KONAWE SELATAN, PROVINSI SULAWESI TENGGARA
}

\author{
Hasbi Trihatmanto ${ }^{1)}$ \\ ${ }^{1)}$ Balai Pengamanan dan Penegakan Hukum Lingkungan Hidup dan Kehutanan \\ Wilayah Sulawesi, Seksi I Makassar, \\ Direktorat Jenderal Penegakan Hukum Lingkungan Hidup dan Kehutanan, \\ Kementerian Lingkungan Hidup dan Kehutanan
}

\begin{abstract}
ABSTRAK
Ruang lingkup pengawasan perizinan lingkungan hidup dilakukan dengan kegiatan 1) Pemeriksaan terhadap dokumen lingkungan hidup dan perizinan yang terkait, 2) Pemeriksaan terhadap fasilitas pengendalian pencemaran air, 3) Pemeriksaan terhadap fasilitas pengendalian pencemaran udara emisi dan ambien, 4) Pemeriksaan terhadap pengelolaan Bahan Berbahaya dan Beracun, 5) Pemeriksaan terhadap pengelolaan Limbah Bahan Berbahaya dan Beracun, 6) Pemeriksaan pengelolaan limbah padat Non B3 dan/atau sampah domestik. Tahapan kegiatan penambangan bijih nikel laterit yang dilakukan di salah satu perusahaan di Kabupaten Konawe Selatan, Provinsi Sulawesi Tenggara antara lain 1) Tahap perencanaan, 2) Land clearing, 3) Pengupasan over burden, 4) Ore getting, 5) Pembuatan cone produksi. Proses penambangan akan menghasilkan produksi bijih nikel. Bijih nikel dari tambang berupa raw nikel diangkut dengan menggunakan Dump Truck dengan kapasitas $20 \mathrm{mt}$. Pengangkutan bahan galian menggunakan Dump Truck menempuh jarak hauling $17 \mathrm{~km}$ dari tambang sampai ke EFO (Exportable Final Ore), penumpukan di EFO dengan system dome yang dikelompokkan sesuai kadar atau level kualitas bahan galian. Material raw nikel yang terkumpulkan di EFO kemudian dimuat ke tongkang yang disesuaikan dengan market permintaan domestik kasaran Ni 1,80 - 1,95\% dengan rata - rata tonase pengapalan lokal 6.000 $7.500 \mathrm{mt}$. Sedangkan untuk pasar ekspor kisaran $\mathrm{Ni}<1,7 \%$ dengan rata - rata tonase pengapalan ekspor $50.000 \mathrm{mt}$. Pada pengawasan yang dilakukan perbandingan antara dokumen Rencana Pemantauan Lingkungan (RPL) dengan hasil pelaporan RPL dan hasil temuan lapangan perusahaan telah melanggar Undang-undang Nomor 32 Tahun 2009 tentang Perlindungan dan Pengelolaan Lingkungan Hidup pada Pasal 20 ayat (3) huruf b, Pasal 67, Pasal 68 huruf c, Peraturan Pemerintah Nomor 82 Tahun 2001 tentang Pengelolaan Kualitas Air dan Pengendalian Pencemaran Air pada Pasal 34 ayat (2) dan (3), Pasal 37, Pasal 40 ayat (2), Peraturan Pemerintah Nomor 41 Tahun 1999 tentang Pengendalian Pencemaran Udara pada Pasal 21 huruf a dan b, Peraturan Pemerintah Nomor 101 Tahun 2014 tentang Pengelolaan Limbah Bahan Berbahaya dan Beracun pada Pasal 12 ayat (1), Pasal 25 ayat (1) huruf b, Peraturan Menteri Lingkungan Hidup Nomor 14 Tahun 2013 tentang Simbol dan Label Limbah Bahan Berbahaya dan Beracun pada Pasal 2 ayat (5) dan Peraturan Menteri Lingkungan Hidup Nomor Nomor 06 tahun 2006 tentang Baku Mutu Air Limbah Bagi Usaha dan/atau Kegiatan Pertambangan bijih Nikel Pasal 8, ayat (1) dan ayat (2). Berdasarkan analisis yuridis yang telah dilakukan, maka dapat disimpulkan bahwa perusahaan tambang bijih nikel tersebut Tidak Taat.
\end{abstract}

Kata Kunci : Bijih Nikel, Lingkungan Hidup, Pengawasan, Peraturan, Perizinan. 


\begin{abstract}
The scope of environmental licensing supervision is carried out with activities 1) Inspection of environmental documents and related permits, 2) Reports of water pollution control facilities, 3) Reports of emission and ambient air pollution control facilities, 4) Reports of the management of Hazardous Substances and Toxic, 5) Inspection of the management of Hazardous and Toxic Waste, 6) Inspection of management of Non toxic and dangerous material solid waste and/or domestic waste. Stages of laterite nickel ore mining activities carried out in one company in Konawe Selatan Regency, Southeast Sulawesi Province include 1) Planning phase, 2) Land clearing, 3) Over-load stripping, 4) Ore getting, 5) Production of cone production. The mining process will produce nickel ore production. Nickel ore from mines in the form of nickel raw is transported using a Dump Truck with a capacity of $20 \mathrm{mt}$. Transportation of mining materials using a Dump Truck takes a hauling distance of $17 \mathrm{~km}$ from the mine to the EFO (Exportable Final Ore), stacking on EFO with a dome system that is grouped according to the level or quality level of minerals. The nickel raw material collected at EFO is then loaded onto a barge which is adjusted to the domestic market demand of $\mathrm{Ni} 1.80-1.95 \%$ with an average local shipping tonnage of 6,000 - 7,500 mt. As for the export market, the range of $\mathrm{Ni}<1.7 \%$ with an average shipping tonnage of 50,000 $\mathrm{mt}$. In monitoring conducted a comparison between Environmental Monitoring Plan (EMP) documents with EMP reporting results and company field findings has violated Law Number 32 of 2009 concerning Environmental Protection and Management in Article 20 paragraph (3) letter b, Article 67, Article 68 letter c, Government Regulation Number 82 of 2001 concerning Management of Water Quality and Water Pollution Control in Article 34 paragraphs (2) and (3), Article 37, Article 40 paragraph (2), Government Regulation Number 41 of 1999 concerning Pollution Control Air in Article 21 letters $a$ and b, Government Regulation Number 101 of 2014 concerning Management of Hazardous and Toxic Waste in Article 12 paragraph (1), Article 25 paragraph (1) letter b, Minister of the Environment Regulation Number 14 of 2013 concerning Symbols and Label of Hazardous and Toxic Waste in Article 2 paragraph (5) and Minister of the Environment Regulation Number 06 of 2006 concerning Wastewater Quality Standards for Businesses and/or Mining Activities for Nickel Ore Article 8 paragraph (1) and paragraph (2).. Based on the juridical analysis that has been done, it can be concluded that the nickel ore mining company is Not Obedient.
\end{abstract}

Keywords: Nickel Ore, Environment, Supervision, Regulation, Licensing.

\title{
A. PENDAHULUAN
}

\section{A.1 Latar Belakang}

Pengendalian pencemaran lingkungan merupakan salah satu bentuk implementasi mandatori dari pasal 71, pasal 72, pasal 73 dan pasal 74 Undang-undang Nomor 32 Tahun 2009 tentang Perlindungan dan Pengelolaan Lingkungan Hidup, dilakukan pengawasan perizinan lingkungan hidup terhadap penanggung jawab usaha dan/atau kegiatan terkait izin lingkungan, izin Pejabat Pengawas Lingkungan Hidup (PPLH) dan perundang-undangan lingkungan hidup yag telah diterbitkan oleh Kementerian Lingkugan Hidup dan Kehutanan.

\section{A.2 Tujuan}

Kegiatan pengawasan penaatan lingkungan hidup merupakan salah satu upaya dalam penegakan hukum lingkungan hidup dan kehutanan untuk mengetahui sampai sejauh mana tingkat ketaatan Pelaku Usaha dan/atau Kegiatan dalam mengelola lingkungan sebagaimana ketentuan kewajiban yang tercantum dalam peraturan perundang-undangan dan perizinan lingkungan hidup. Hal ini sejalan dengan pasal 71 Undang-Undang Nomor 32 Tahun 2009 tentang Perlindungan dan Pengelolaan Lingkungan Hidup yang menyatakan bahwa "Menteri, gubernur, bupati/walikota sesuai dengan kewenangannya wajib melakukan pengawasan terhadap ketaatan penanggung jawab usaha dan/atau kegiatan atas ketentuan yang ditetapkan dengan peraturan perundangundangan di bidang perlindungan dan pengelolaan lingkungan hidup". 
Ruang lingkup pengawasan perizinan lingkungan hidup ini dilakukan dengan kegiatan sebagai berikut :

1. Pemeriksaan terhadap dokumen lingkungan hidup dan perizinan yang terkait;

2. Pemeriksaan terhadap fasilitas pengendalian pencemaran air;

3. Pemeriksaan terhadap fasilitas pengendalian pencemaran udara emisi dan ambien;

4. Pemeriksaan terhadap pengelolaan Bahan Berbahaya dan Beracun;

5. Pemeriksaan terhadap pengelolaan Limbah Bahan Berbahaya dan Beracun; dan

6. Pemeriksaan pengelolaan limbah padat Non B3 dan/atau sampah domestik.

\section{A.3 Metodologi Penelitian}

Kegiatan pengawasan penaatan lingkungan hidup terhadap salah satu kegiatan usaha penambangan bijih nikel yang terletak di Kabupaten Konawe Selatan, Provinsi Sulawesi Tenggara meliputi :

1. Pertemuan pendahuluan dengan pihak perusahaan yang diwakili oleh HRGA Manager, Kepala Teknik Tambang, Wakil Kepala Teknik Tambang dan Safety Officer dengan memperkenalkan tim pengawasan, tujuan pengawasan dan menjelaskan ruang lingkup dan agenda pengawasan;

2. Pemeriksaan terhadap dokumen lingkungan hidup dan perizinan yang terkait;

3. Pemeriksaan penaatan pelaksanaan pengendalian pencemaran air meliputi :

- Pemeriksaan sumber-sumber pengeluaran air limbah

- Pemeriksaan sarana pengolahan air limbah

- Pemeriksaan sarana pengukuran debit air limbah yang dibuang

- Perhitungan beban pencemaran

4. Pemeriksaan penaatan pelaksanaan pengendalian pencemaran udara meliputi :

- Pemeriksaan sumber-sumber pencemaran udara

- Pemeriksaan lubang pengambilan sampel dan sarana prasarannya

- Pemeriksaan sarana pengendalian pencemaran udara

- Pemeriksaan baku mutu ambien

- Pemeriksaan baku mutu emisi udara sumber tidak bergerak

- Pemeriksaan baku mutu emisi udara sumber bergerak

5. Pemeriksaan penaatan pengelolaan Bahan Berbahaya dan Beracun (B3) meliputi :

- Pemeriksaan Bahan Berbahaya dan Beracun (B3) yang digunakan

- Pemeriksaan Gudang Penyimpanan Bahan Berbahaya dan Beracun (B3)

- Pemeriksaan dokumen MSDS Bahan Berbahaya dan Beracun (B3)

6. Pemeriksaan penaatan pengelolaan Limbah Bahan Berbahaya dan Beracun (LB3) meliputi

- Pemeriksaan sumber-sumber limbah B3

- Pemeriksaan TPS Limbah B3

- Pemeriksaan dokumen manifest Limbah B3

- Neraca Limbah B3

7. Pemeriksaan penaatan pengelolaan Sampah Domestik (Limbah Non B3) meliputi :

- Pemeriksaan sarana dan prasarana pengolahan sampah domestik

- Pemeriksaan pengelolaan akhir Sampah Domestik

8. Pemeriksaan Rehabilitasi Kerusakan Lahan;

9. Wawancara dengan pihak-pihak terkait;

10. Pengambilan foto di lokasi tambang;

11. Penyusunan dan penandatanganan berita acara pengawasan dan berita acara pengambilan foto; dan

12. Pertemuan penutup dengan pihak perusahaan dengan menyampaikan hasil pengawasan berupa berita acara pengawasan dan berita acara pengambilan foto. 


\section{A.4 Pendekatan Pemecahan Masalah}

Lokasi salah satu kegiatan usaha penambangan bijih nikel yang terletak di Kabupaten Konawe Selatan, Provinsi Sulawesi Tenggara memiliki luas area seluas 800 Ha sesuai dengan Surat Keputusan Bupati Konawe Selatan mengenai Izin Kuasa Pertambangan (KP) dan Surat Keputusan Bupati Konawe Selatan mengenai Izin Usaha Pertambangan (IUP) Operasai Produksi. Lokasi tersebut berjarak sekitar \pm 120 Kilometer dari Kota Kendari, Ibu Kota Provinsi Sulawesi Tenggara.

Saat ini pelaksanaan kegiatan di tapak proyek periode Juli-Desamber tahun 2018 dilaksanakan kegiatan pada tahap operasi meliputi serangkaian kegiatan yaitu 1) Kegiatan eksplorasi, 2) Konstruksi/infrastruktur, 3) Kegiatan penambangan, 4) Pengangkutan dan penimbunan bahan galian, dan 5) Inventory, 6) Reklamasi lahan bekas tambang. Luas area lahan yang telah di reklamasi selama periode tahun 2018 seluas $25 \mathrm{Ha}$ dengan penanaman pohon (planting) dan tanaman penutup (ground cover) tanah akan direncanakan pada out cast dump menunggu daerah yang ada di back filling. Penanaman tanaman penutup tanah pada lereng-lereng out cast/pit dump bertujuan untuk mengurangi atau mencegah kerusakan fisik lahan akibat laju erosi tanah maupun longsor (sliding). Lokasi penambangan bijih nikel berbatasan dengan hutan produksi dan lahan pertanian milik masyarakat serta kegiatan sejenis.

Tahapan kegiatan penambangan bijih nikel laterit yang dilakukan di salah satu perusahaan di Kabupaten Konawe Selatan, Provinsi Sulawesi Tenggara antara lain :

1. Tahap Perencanaan

2. Land Clearing

3. Pengupasan Over Burden

4. Ore Getting

5. Pembuatan Cone Produksi

\section{A.4.1 Tahap Perencanaan}

Pada tahap perencanaan ini dilakukan beberapa kegiatan berikut :

a. Persiapan lokasi penambangan dengan melakukan perencanaan awal untuk menentukan lokasi penambangan ditentukan berdasarkan data hasil eksplorasi pada mineplan engineer.

b. Pengecekan hasil data eksplorasi berupa data yang telah diperoleh dari divisi perencanaan tambang berupa peta dan estimasi jumlah cadangan dilakukan observasi ulang untuk memastikan kondisi real di lapangan.

c. Penentuan waktu penambangan yang akan dilakukan apabila telah mendapat persetujuan oleh Kepala Teknik Tambang atau Wakil Kepala Teknik Tambang.

d. Penentuan target produksi penambangan yang akan ditentukan sesuai dengan kebutuhan pemasaran.

e. Menganalisa data lapangan dan data hasil eksplorasi.

f. Membuat plan dan menghitung volume material yang akan ditambang.

g. Melakukan observasi langsung ke lapangan pada lokasi yang direncanakan.

\section{A.4.2 Land Clearing}

Land clearing merupakan kegiatan pembersihan tumbuhan/vegetasi dilokasi yang akan dilakukan penambangan.

\section{A.4.3 Pengupasan Over Burden}

Pengupasan over burden merupakan kegiatan pemindahan material dengan nilai kadar rendah/tidak ekonomis agar tidak menggangu/tercampur dengan material yang akan di tambang.

\section{A.4.4 Ore Getting}

Pada tahap ore getting dilakukan beberapa tahapan berikut :

a. Ore getting adalah kegiatan penggalian ore dengan nilai ekonomis sesuai cut off grade. 
b. Kegiatan ore getting dilakukan menggunakan Excavator Backhoe.

c. Pengawasan sangat penting dilakukan pada kegiatan ore getting.

d. Composite ore getting.

\section{A.4.5 Pembuatan Cone Produksi}

Pada tahap cone produksi dilakukan beberapa tahapan berikut :

1. Cone penambangan dibuat selama kegiatan ore getting.

2. 1 (satu) cone penambangan dibuat sebanyak \pm 15 incrimen $(225 \mathrm{mt})$.

3. Jumlah cone penambangan dibuat sesuai dengan target produksi harian dengan memperhatikan kualitas kadarnya.

4. Hasil produksi (cone) selanjutnya akan dilakukan pengambilan sampel untuk keperluan analisa laboratorium.

\section{A.4.6 Pengangkutan dan Penimbunan Bahan Galian}

Proses penambangan akan menghasilkan produksi bijih nikel. Bijih nikel dari tambang berupa raw nikel diangkut dengan menggunakan Dump Truck dengan kapasitas $20 \mathrm{mt}$. Pengangkutan bahan galian menggunakan Dump Truck menempuh jarak hauling $17 \mathrm{~km}$ dari tambang sampai ke EFO (Exportable Final Ore), penumpukan di EFO dengan system dome yang dikelompokkan sesuai kadar atau level kualitas bahan galian. Material raw nikel yang terkumpulkan di EFO kemudian dimuat ke tongkang yang disesuaikan dengan market permintaan domestik kasaran $\mathrm{Ni} 1,80$ $1,95 \%$ dengan rata - rata tonase pengapalan lokal $6.000-7.500 \mathrm{mt}$. Sedangkan untuk pasar ekspor kisaran $\mathrm{Ni}<1,7 \%$ dengan rata - rata tonase pengapalan ekspor $50.000 \mathrm{mt}$.

Alat yang digunakan untuk pemuatan dan pengangkutan raw material ore dari tambang menggunakan Dump Truck kontraktor yang disewa sesuai kontrak kerja. Area - area tambang yang telah tereksploitasi menghasilkan void atau lubang bekas tambang dimana area tersebut diremajakan lagi dengan penimbunan ulang (back fill) material over burden (OB) pada saat penggalian awal. Proses back fill menggunakan alat berat Bulldozer dan Excavator yang selanjutnya ditata ulang pada saat kegiatan reklamasi.

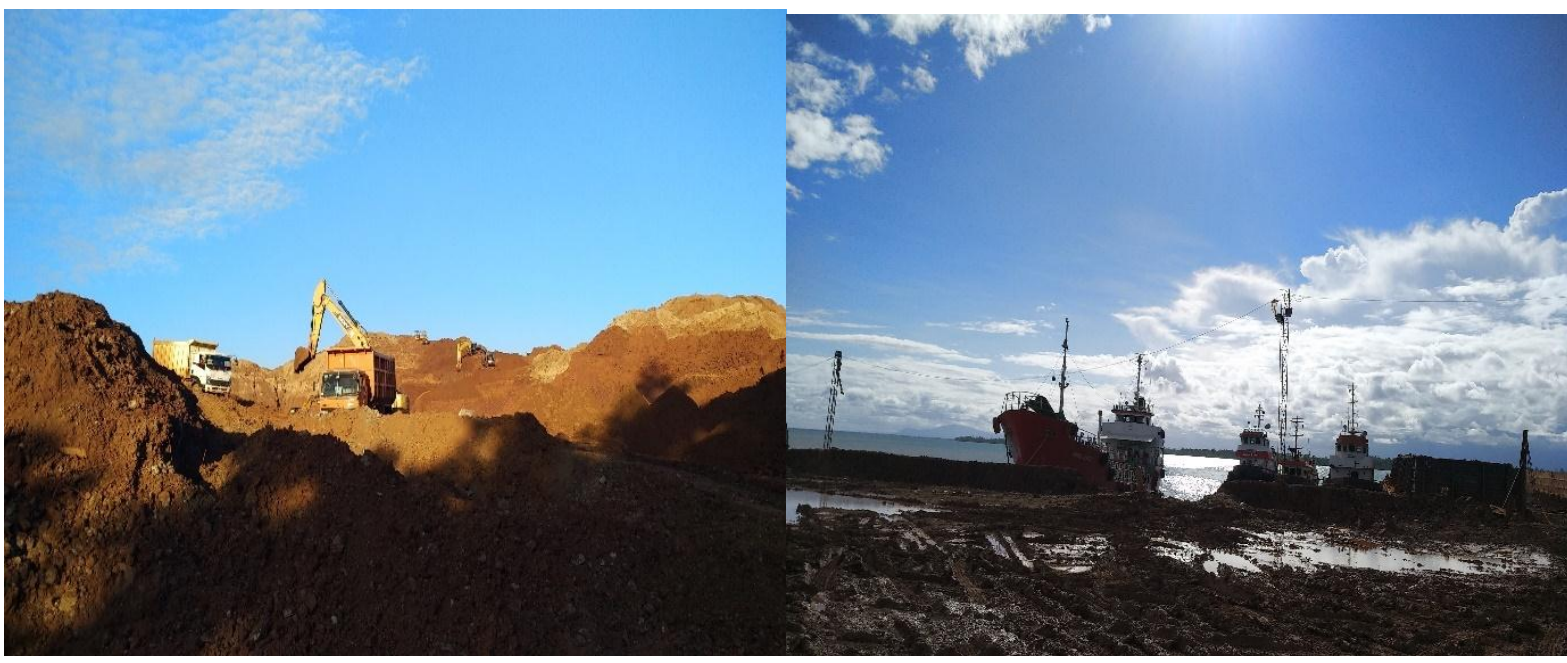

Gambar 1. Kegiatan Penambangan di Salah Satu Perusahaan Tambang Bijih Nikel

di Kabupaten Konawe Selatan, Provinsi Sulawesi Tenggara

Kegiatan pembangunan jalan tambang dan pelabuhan khusus memanfaatkan lahan seluas 1,470 Ha. Jenis-jenis usaha dan/atau kegiatan yang dibangun meliputi stockpile laut seluas $100.000 \mathrm{~m}^{2}$, bangunan sisi darat seluas $30.000 \mathrm{~m}^{2}$ dan sisi laut $4.500 \mathrm{~m}^{2}$. Fasilitas yang dibangun baik pada sisi laut maupun pada sisi darat berupa pekerjaan sipil yang meliputi : 1) Pembuatan jalan tambang, 2) 
Fasilitas pelabuhan: trestel, dinding pelabuhan, perlengkapan pelabuhan, pengerasan pelabuhan dan navigation aids, 3) Fasilitas penunjang pelabuhan, terminal control dan pergudangan, 4) Fasilitas nasitasi lingkungan (pembangunan fasilitas drainase), 5) Pekerjaan struktur baja dan mekanik, 6) Pembuatan pagar, 7) Pembuatan talud, 8) Penataan areal stockpile dalam dan stockpile luar dan 9) Penataan Ruang Terbuka Hijau (RTH) /tata hijau/landscaping 
Tabel 1. Perbandingan antara dokumen Rencana Pemantauan Lingkungan dan Rencana Pemantauan Lingkungan (RKL/RPL) dengan hasil pelaporan RKL/RPL dan hasil temuan lapangan

\begin{tabular}{|c|c|c|c|c|c|}
\hline \multirow[t]{2}{*}{ NO } & \multirow{2}{*}{$\begin{array}{l}\text { DAMPAK } \\
\text { PENTING YANG } \\
\text { DIPANTAU }\end{array}$} & \multirow[t]{2}{*}{ PENGELOLAAN } & \multirow[t]{2}{*}{ PEMANTAUAN } & \multicolumn{2}{|c|}{$\begin{array}{c}\text { TEMUAN LAPANGAN } \\
\text { (Hasil Laporan Pelaksanaan RKL-RPL Tahun 2018) }\end{array}$} \\
\hline & & & & PENGELOLAAN & PEMANTAUAN \\
\hline 1 & 2 & 3 & 4 & 5 & 6 \\
\hline 1. & $\begin{array}{l}\text { Penurunan Kualitas } \\
\text { Udara dan } \\
\text { Peningkatan } \\
\text { Intensitas } \\
\text { Kebisingan }\end{array}$ & $\begin{array}{l}\text { Selama pengangkutan dan } \\
\text { mobilisasi alat, untuk } \\
\text { mengurangi debu jalan yang } \\
\text { dilalui, maka komitmen } \\
\text { perusahaan menjaga ramah } \\
\text { lingkungan. Pemantauan kualitas } \\
\text { udara di lokasi kegiatan dengan } \\
\text { metode pengambilan sampel dan } \\
\text { analisis laboratorium yang } \\
\text { bertujuan untuk mengetahui } \\
\text { sejauh mana peningkatan } \\
\text { kandungan debu dan unsur kimia } \\
\text { akibat kegiatan operasional } \\
\text { penambangan. }\end{array}$ & \begin{tabular}{lr} 
Pemantuan & \multicolumn{2}{c}{ dilakukan } \\
langsung di lokasi dan \\
dianalisis laboratorium. \\
Pemantauan dilakukan \\
langsung di lokasi \\
menggunakan Sound Level \\
Meter yang akan diukur \\
tingkat kebisingannya.
\end{tabular} & $\begin{array}{l}\text { - Penyiraman jalan yang berpotensi } \\
\text { menghasilkan debu secara rutin } \\
\text { terutama pada saat kegiatan } \\
\text { pengangkutan material dan bahan } \\
\text { tambang. } \\
\text { - Pengaturan frekuensi kendaraan dan } \\
\text { membatasi kecepatannya. } \\
\text { - Penggunaan ear plug bagi pekerja } \\
\text { dan masyarakat yang beraktivitas di } \\
\text { sekitar proyek. }\end{array}$ & $\begin{array}{l}\text { Pemantauan emisi udara dilakukan oleh pihak } \\
\text { ke } 3 \text { (tiga) yaitu UPTD Balai Laboratorium } \\
\text { Kesehatan Daerah Dinas Kesehatan Provinsi } \\
\text { Sulawesi Tenggara (Laboratorium } \\
\text { Terakreditasi dengan No. LP-674-IDN } \\
\text { berlaku hingga 01 Februari 2022). Parameter } \\
\text { emisi udara ambien sesuai dengan Peraturan } \\
\text { Pemerintah Nomor } 41 \text { Tahun 1999. Ada satu } \\
\text { parameter (dust fall) yang tidak diuji. Tidak } \\
\text { menguji Uji Emisi Udara Sumber Tidak } \\
\text { Bergerak untuk Penambangan Nikel pada } \\
\text { Peraturan Menteri Lingkungan Hidup Nomor } \\
\text { 04 Tahun 2014. }\end{array}$ \\
\hline 2. & $\begin{array}{l}\text { Penurunanan } \\
\text { Kualitas Air }\end{array}$ & $\begin{array}{l}\text { a. Membuat saluran drainase } \\
\text { tambang } \\
\text { b. Pembuatan perangkap } \\
\text { sedimen } \\
\text { c. Pembuatan saluran drainase } \\
\text { dari kolam sedimen ke sungai } \\
\text { d. Perbaikan kolam sedimen }\end{array}$ & $\begin{array}{lr}\text { Pengukuran } & \text { suhu } \\
\text { menggunakan Thermometer, } & \text { dengan } \\
\text { kekeruhan } & \text { durbidimeter, TSS dengan } \\
\text { Gravimetrik, pH dengan } & \text { PHetrik, salinitas } \\
\text { Potensiometrik, } & \text { dengan elektromaknetik, Fe, } \\
\text { Cd, Ni dengan Atomic, } \\
\text { absorbitionalat timbangan } \\
\text { elektrik BOD dan COD } \\
\text { dengan Tritrasi, DO dengan } \\
\text { DO meter, dan amoniak } \\
\text { dengan Spektrofotometri. }\end{array}$ & $\begin{array}{l}\text { Pembuatan kolam sedimentasi dilokasi } \\
\text { penambangan dan saluran drainase dari } \\
\text { kolam sedimen ke sungai sekitar lokasi } \\
\text { penambangan nikel. }\end{array}$ & $\begin{array}{l}\text { Pemantauan Kualitas Air Sungai dilakukan } \\
\text { oleh pihak ke } 3 \text { (tiga) yaitu UPTD Balai } \\
\text { Laboratorium Kesehatan Daerah Dinas } \\
\text { Kesehatan Provinsi Sulawesi Tenggara } \\
\text { (Laboratorium Terakreditasi dengan No. LP- } \\
\text { 674-IDN berlaku hingga 01 Februari 2022). } \\
\text { Telah melakukan pengujian air sungai sesuai } \\
\text { dengan Peraturan Pemerintah Nomor } 82 \text { tahun } \\
\text { 2001. Perusahaan tidak melakukan Uji Air } \\
\text { Limbah sesuai yang dipersyaratkan dalam } \\
\text { IPLC untuk Penambangan Nikel pada } \\
\text { Peraturan Menteri Lingkungan Hidup Nomor } \\
\text { 09 Tahun } 2006 \text {. }\end{array}$ \\
\hline 3. & $\begin{array}{l}\text { Sedimentasi dan } \\
\text { Erosi }\end{array}$ & $\begin{array}{l}\text { a. Membuat saluran drainase } \\
\text { tambang }\end{array}$ & $\begin{array}{ll}\text { Pengukuran } & \text { TSS } \quad(\mathrm{mg} / \mathrm{l}) \\
\text { diukur } & \text { menggunakan }\end{array}$ & $\begin{array}{l}\text { a. Perusahaan telah membuat saluran } \\
\text { drainase tambang }\end{array}$ & $\begin{array}{l}\text { Perusahaan belum melakukan treatment untuk } \\
\text { pengukuran TSS di sedimen pond/setling }\end{array}$ \\
\hline
\end{tabular}




\begin{tabular}{|c|c|c|c|c|c|}
\hline \multirow[t]{2}{*}{ NO } & \multirow{2}{*}{$\begin{array}{l}\text { DAMPAK } \\
\text { PENTING YANG } \\
\text { DIPANTAU } \\
\end{array}$} & \multirow[t]{2}{*}{ PENGELOLAAN } & \multirow[t]{2}{*}{ PEMANTAUAN } & \multicolumn{2}{|c|}{$\begin{array}{c}\text { TEMUAN LAPANGAN } \\
\text { (Hasil Laporan Pelaksanaan RKL-RPL Tahun 2018) }\end{array}$} \\
\hline & & & & PENGELOLAAN & PEMANTAUAN \\
\hline \multirow[t]{2}{*}{1} & 2 & 3 & 4 & 5 & 6 \\
\hline & & $\begin{array}{l}\text { b. Pembuatan perangkap } \\
\text { sedimen } \\
\text { c. Pembuatan saluran drainase } \\
\text { dari kolam sedimen ke sungai } \\
\text { d. Perbaikan kolam sedimen }\end{array}$ & $\begin{array}{l}\text { metode analisis gravimetric } \\
\text { dengan peralatan timbang } \\
\text { analitik }\end{array}$ & $\begin{array}{l}\text { b. } \begin{array}{l}\text { Perusahaan dalam } \\
\text { pembuatan perangkap sedimen } \\
\text { (sump) }\end{array} \\
\text { c. Perusahaan dalam proses } \\
\text { pembuatan saluran drainase dari } \\
\text { kolam sedimen ke sungai } \\
\text { d. Perusahaan dalam proses perbaikan } \\
\text { kolam sedimen }\end{array}$ & pond. \\
\hline 4. & Flora Darat & $\begin{array}{l}\text { a. Pembinaan habitat pada } \\
\text { kawasan yang tidak terbuka } \\
\text { b. Pembuatan papan larangan } \\
\text { himbauan pelestarian satwa } \\
\text { c. Kegiatan reklamasi lahan dan } \\
\text { stabilitas tanah }\end{array}$ & $\begin{array}{l}\text { 1. Analisis vegetasi dengan } \\
\text { metode kuadran untuk } \\
\text { mendapatkan nilai } \\
\text { indeks keragamannya } \\
\text { 2. Pengukuran di atas peta } \\
\text { untuk melihat realisasi } \\
\text { penanaman dan luas } \\
\text { lahan }\end{array}$ & $\begin{array}{l}\text { a. Perusahaan telah melakukan } \\
\text { pembinaan habitat pada kawasan } \\
\text { yang tidak terbuka diantara blok } \\
\text { Utara dan blok Selatan berupa } \\
\text { dalam bentuk penanaman jambu } \\
\text { mete } \\
\text { b. Dalam dokumen } \\
\text { Penambangan BMDAL } \\
\text { Bijih Nikel }\end{array}$ & $\begin{array}{l}\text { 1. Parameter lingkungan yang dipantau } \\
\text { adalah flora darat, dengan tolak ukur } \\
\text { dampak yakni hilangnya vegetasi-vegetasi } \\
\text { penutup lahan di areal penambangan dan } \\
\text { non tambang yang meliputi luas areal } \\
\text { vegetasi, kerapatan jenis, penyebaran } \\
\text { jenis, dominasi jenis dan keanekaragaman } \\
\text { jenis. }\end{array}$ \\
\hline & & & 3. Hasil area survei & $\begin{array}{l}\text { Perusahaantidak ada Fauna Darat. } \\
\text { c. Perusahaan telah melakukan } \\
\text { reklamasi pada areal yang telah } \\
\text { ditambang }\end{array}$ & $\begin{array}{l}\text { 2. Berdasarkan tutupan vegetasinya ada } 8 \\
\text { tansek pengamatan. } \\
\text { 3. Jenis tumbuhan herba penambnagan bijih } \\
\text { nikel perusahaan yaitu alang - alang, rodu, } \\
\text { komba - komba, bambu rambat, pulutan, } \\
\text { putri malu, teki dan pakis tanah/paka. }\end{array}$ \\
\hline 5. & Biota Air & $\begin{array}{l}\text { a. Merencanakan penambangan } \\
\text { dengan baik } \\
\text { b. Membuat parit drainase } \\
\text { c. Membuat kolan sedimen } \\
\text { d. Membuat teras di front } \\
\text { tambang }\end{array}$ & $\begin{array}{l}\text { Analisis menggunakan } \\
\text { metode pengambilan sampel } \\
\text { dilakukan dengan } \\
\text { menggunakan kuadran } \\
\text { ukuran } 1 \times 1 \text { m sedalam } \pm 30 \\
\text { cm pada substat pasir, } \\
\text { pengamatan pada komunitas } \\
\text { benthos pada perairan } \\
\text { sekitar sungai menggunakan } \\
\text { metode transek garis }\end{array}$ & $\begin{array}{l}\text { a. Perusahaan telah merencanakan } \\
\text { penambangan sesuai dengan kaidah } \\
\text { penambangan yang baik dan benar } \\
\text { b. Perusahaan telah membuat parit } \\
\text { drainase } \\
\text { c. Perusahaan telah membuat kolam } \\
\text { sedimen } \\
\text { d. Membuat teras di front tambang }\end{array}$ & $\begin{array}{l}\text { Pemantauan biota air berupa Plankton dan } \\
\text { Bethos dilakukan oleh pihak ke } 3 \text { (tiga) yaitu } \\
\text { Laboratorium Kimia Fakultas Matematika dan } \\
\text { Ilmu Pengetahuan Alam Universitas Halu } \\
\text { Oleo berdasarkan Keputusan Menteri } \\
\text { Lingkungan Hidup Nomor 51 tahun } 2004 \\
\text { tentang Baku Mutu untuk Biota Laut dan } \\
\text { Perairan Pelabuhan. }\end{array}$ \\
\hline
\end{tabular}




\begin{tabular}{|c|c|c|c|c|c|}
\hline \multirow[t]{2}{*}{ NO } & \multirow{2}{*}{$\begin{array}{l}\text { DAMPAK } \\
\text { PENTING YANG } \\
\text { DIPANTAU }\end{array}$} & \multirow{2}{*}{ PENGELOLAAN } & \multirow{2}{*}{ PEMANTAUAN } & \multicolumn{2}{|c|}{$\begin{array}{c}\text { TEMUAN LAPANGAN } \\
\text { (Hasil Laporan Pelaksanaan RKL-RPL Tahun 2018) }\end{array}$} \\
\hline & & & & PENGELOLAAN & PEMANTAUAN \\
\hline 1 & 2 & 3 & 4 & 5 & 6 \\
\hline 6. & $\begin{array}{l}\text { Kesempatan Kerja } \\
\text { dan Peluang } \\
\text { Berusaha }\end{array}$ & $\begin{array}{l}\text { a. Mempriotaskan penduduk } \\
\text { local pada setiap penambahan } \\
\text { tenaga kerja } \\
\text { b. Memberi upah dan fasilitas } \\
\text { yang kompetitif kepada } \\
\text { penduduk local } \\
\text { c. Memberi pelatihan dan } \\
\text { pendidikan kepada penduduk } \\
\text { local sampai memenuhi } \\
\text { kualifikasi tenaga kerja yang } \\
\text { dibutuhkan perusahaan } \\
\text { d. Memberi kesempatan pada } \\
\text { penduduk lokal untuk } \\
\text { menyiapkan alat dan bahan } \\
\text { material }\end{array}$ & $\begin{array}{l}\text { Wawancara dan } \\
\text { pengumpulan data sekunder, } \\
\text { wawancara dilakukan pada } \\
\text { tenaga kerja, aparat desa, } \\
\text { penduduk }\end{array}$ & $\begin{array}{l}\text { a. Tenaga kerja perusahaan direkrut } \\
\text { sesuai dengan keahlian masing- } \\
\text { masing dan memprioritas tenaga } \\
\text { kerja dari masyarakat sekitar } \\
\text { lokasi penambangan dengan } \\
\text { presentase } 80 \% \text { tenaga lokal. } \\
\text { b. Upah diberikan perbulan sesuai } \\
\text { UMK Kabupaten Konawe Selatan } \\
\text { c. Pekerja diberi pelatihan berupa } \\
\text { materi K3 setiap hari Senin, } \\
\text { Kamis dan Jum'at. } \\
\text { d. Perusahaan telah memberi } \\
\text { kesempatan kepada penduduk } \\
\text { lokal untuk menyiapkan alat dan } \\
\text { bahan material berupa sewa alat } \\
\text { dan penyediaan bahan bangunan }\end{array}$ & $\begin{array}{l}\text { Tenaga kerja yang terlibat langsung dengan } \\
\text { perusahaan terdiri } 86 \text { tenaga lokal dan } 21 \\
\text { tenaga non lokal. }\end{array}$ \\
\hline
\end{tabular}




\section{B.2 Pemeriksaan Pengendalian Pencemaran Air}

Perusahaan memiliki Izin Pembuangan Limbah Cair (IPLC) yang dikeluarkan oleh Bupati Konawe Selatan pada tahun 2016 tentang Izin Pembuangan Limbah Cair Kegiatan Penambangan Bijih Nikel di Kabupaten Konawe Selatan, tanggal 12 Juli 2016 berlaku selama 5 (lima) tahun sampai 12 Juli 2021. Pada pengawasan yang dilakukan, ditemukan perusahaan tidak memasang titik penaatan di Batu Kodok dan SEI Roraya. Air limbah yang dikeluarkan dari outlet ke Sungai Roraya, Kecamatan Tinanggea, Kabupaten Konawe Selatan. Acuan Peraturan Menteri Lingkungan Hidup dalam Izin Pembuangan Air Limbah Cair (IPLC) tidak beracuan pada peraturan yang berlaku (seharusnya Peraturan Menteri Lingkungan Hidup Nomor 9 tahun 2006) dan tidak melakukan swapantau air limbah pada 2 (dua) titik penaatan sesuai dipersyaratkan dalam IPLC yang dimiliki, tidak memasang papan penaatan pada lokasi titik sampling, tidak mengukur debit air limbah setiap hari, tidak melakukan pencatatan waktu apabila terjadi gangguan dan tidak melakukan swapantau air limbah pada titik penaatan sesuai dipersyarakan sehingga tidak melaporkan hasil pemantauan pembuangan limbah cairPerusahaan memiliki pengolahan air limbah pada sediment pond sebanyak 1 (satu) yang terdiri dari 3 (tiga) kolam pengendapan berukuran ukuran 6x6×2 $\mathrm{m}$ dan jarak antara sump (bak penampungan sementara air limbah sebelum dialirkan ke Sungai Roraya) antara $200-300 \mathrm{~m}$. Bak penampungan sementara air limbah sebelum dialirkan ke Sungai Roraya (sump) yang berukuran 10 x 10 m. Kondisi sediment pond hanya berupa bak kolam setinggi $\pm 40 \mathrm{~cm}$, tidak memasang pipa saluran pengeluaran dalam bentuk paralon atau drum kecil (gorong-gorong) sesuai kewajiban dalam dokumen lingkungan. Kondisi lantai dasar sediment pond tidak dipasang penyaring pasir yang terdiri dari pasir, batu koral, batu kerikil, ijuk atau sarang sesuai kewajiban dalam dokumen lingkungan. Perusahaan juga tidak menghitung beban pencemaran air limbah, tidak mengelola air lubang galian tambang (void) sesuai dipersyaratkan, tidak melakukan pencatatan $\mathrm{pH}$ dan debit harian air limbah serta tidak memiliki Standart Operating Procedure (SOP) dan tanggap darurat pengendalian pencemaran air limbah.

\section{B.3 Pemeriksaan Pengendalian Pencemaran Udara}

Perusahaan memiliki 4 (empat) sumber emisi udara yang terdiri dari 2 genset dengan kapasitas 60 KVA dan 2 genset dengan kapasitas 80 KVA. Perusahaan tidak melakukan pemantauan kualitas udara seluruh emisi cerobong genset sesuai dipersyaratkan, tidak melakukan pemenuhan parameter baku mutu kualitas udara seluruh emisi cerobong genset sesuai dipersyaratkan, tidak melaporkan hasil pengukuran kualitas udara seluruh emisi cerobong genset sesuai dipersyaratkan, tidak memenuhi ketentuan teknis sesuai dipersyaratkan dalam Keputusan Kepala Badan Pengendalian Lingkungan Nomor 205 Tahun 1996, tidak melakukan pengukuran tingkat Getaran sesuai dipersyaratkan dalam Keputusan Menteri Lingkungan Hidup Nomor 49 Tahun 1996 tentang Baku Tingkat Getaran dan tidak melakukan pengukuran Emisi Sumber Bergerak pada seluruh kendaraan sesuai dipersyaratkan dalam Lampiran 1 F - Peraturan Menteri Lingkungan Hidup Nomor 04 Tahun 2009.

\section{B.4 Pemeriksaan Pengelolaan Bahan Berbahaya dan Beracun (B3)}

Perusahaan memiliki Izin Penyimpanan Sementara Limbah Bahan Berbahaya dan Beracun (TPS LB3) yang diterbitkan oleh Bupati Konawe Selatan pada tahun 2016 tentang Izin Penyimpanan Sementara Limbah Bahan Berbahaya dan Beracun Kegiatan Penambangan Bijih Nikel di Kabupaten Konawe Selatan tanggal 12 Juli 2016 berlaku selama 5 (lima) tahun sampai 12 juli 2021, dalam izin dijelaskan bahwa limbah B3 yang dismpan dalam tempat penyimpanan Limbah B3 adalah oli bekas, limbah suku cadang dan sejenisnya. Berdasarkan hasil pengawasan di lapangan oleh tim pengawasan diketahui bahwa sumber dan jenis limbah B3, namun tidak dicantumkan dalam izin TPS limbah B3 adalah: 
Tabel 2. Jenis Limbah yang Disimpan di TPS LB3

\begin{tabular}{cll}
\hline No. & \multicolumn{1}{c}{ Jenis Limbah } & \multicolumn{1}{c}{ Sumber } \\
\hline 1. & Oli Bekas & Pemeliharaan genset dan kendaraan \\
2. & Aki Bekas & Genset dan kendaraan \\
3. & Majun & Pemeliharaan genset dan kendaraan \\
4. & Filter Bekas & Genset dan kendaraan \\
5. & Kaleng Bekas & Perkantoran \\
6. & Lampu mercuri & Perkantoran, mess karyawan \\
7. & Drum kemasan & Kemasan berasal pemeliharaan genset \\
\end{tabular}

\section{B.5 Pemeriksaan Pengelolaan Limbah Bahan Berbahaya dan Beracun (LB3)}

Seluruh isi penjelasan dalam Izin penyimpanan limbah B3 yang dimiliki tidak sesuai dipersyaratkan dalam peraturan yang berlaku. Pada saat tim melakukan pengawasan, kondisi tempat penyimpanan sementara limbah B3 tidak sesuai dipersyaratkan dalam Keputusan Kepala Badan Pengendalian Lingkungan Nomor 01 tahun 1995 tentang Tata Cara dan Persyaratan Teknis Penyimpanan dan Pengumpulan Limbah Bahan Berbahaya dan Beracun antara lain tidak terdapat simbol di luar dan didalam bangunan fisik TPS limbah B3, tidak memiliki Standart Operating Procedure (SOP) tanggap darurat dan Standart Operating Procedure (SOP) pengemasan limbah B3, tidak memiliki peralatan keselamatan dan kesehatan kerja seperti kotak P3K dan pancuran air untuk tubuh/mata (shower/eye wash, tidak memiliki peralatan pemadam kebakaran (APAR), tidak memiliki alat penerangan, tidak memiliki alarm (alat/tanda emergency), tidak diberi alas/pallet kemasan limbah B3, terjadi penumpukan limbah B3 dalam TPS limbah B3, terjadi percampuran antara limbah B3 dan non limbah B3, tidak dilakukan dengan baik housekeeping pada TPS limbah B3, seluruh kemasan limbah B3 tidak dilengkapi dengan simbol dan label (keterangan limbah B3), melebihi masa penyimpanan limbah B3 dan tidak mengelola limbah B3 (oli bekas dalam bentuk oil trap, kemasan terkontaminasi, majun) pada workshop sesuai dipersyaratkan dalam dokumen lingkungan (RKL-RPL) dan sesuai peraturan yang berlaku, tidak memiliki kerjasama dengan pengelolaan lanjutan limbah B3 yang dihasilkan sesuai dipersyaratkan dalam peraturan yang berlaku, tidak mencatat limbah yang dihasilkan, tidak memiliki logbook dan tidak memiliki neraca limbah B3 dan tidak memiliki manifest limbah B3.

\section{B.6 Pemeriksaan Pengelolaan Limbah Bahan Padat Non B3 dan/atau Sampah Domestik}

Perusahaan menghasilkan limbah padat non B3 dan/atau sampah domestik yang berasal dari kantor, mess dan workshop, memiliki tempat sampah terpilah ditempatkan di area kantor dan workshop, namun tidak memiliki neraca pengelolaan sampah domestik dan tidak memiliki bank sampah serta pengolahan sampah domestik tidak sesuai dipersyaratkan dalam peraturan yang berlaku (Undangundang Nomor 18 tahun 2008 tentang Pengelolaan Sampah).

\section{B.7 Hasil Analisis Yuridis}

Berdasarkan hasil pengawasan penaatan perizinan lingkungan hidup yang dilakukan, salah satu perusahaan tambang bijih nikel di Kabupaten Konawe Selatan, Provinsi Sulawesi Tenggara telah melakukan pelanggaran :

a. Tidak melakukan pengendalian pencemaran air limbah.

Berdasarkan hal tersebut telah melanggar:

Pasal 20 ayat (3) huruf b Undang-undang Nomor 32 Tahun 2009 tentang Perlindungan dan Pengelolaan Lingkungan Hidup, yang menyatakan bahwa:

"(3) Setiap orang diperbolehkan untuk membuang limbah ke media lingkungan hidup dengan persyaratan: $b$. mendapat izin dari Menteri, gubernur, atau bupati/walikota sesuai dengan kewenangannya". 
Pasal 68 huruf c Undang-undang Nomor 32 Tahun 2009 tentang Perlindungan dan Pengelolaan Lingkungan Hidup, yang menyatakan bahwa:

"Setiap orang yang melakukan usaha dan/atau kegiatan berkewajiban: c. menaati ketentuan tentang baku mutu lingkungan hidup dan/atau kriteria baku kerusakan lingkungan hidup”.

Pasal 34 ayat (2) dan (3) Peraturan Pemerintah Nomor 82 Tahun 2001 tentang Pengelolaan Kualitas Air dan Pengendalian Pencemaran Air, yang menyatakan bahwa:

“(2) Setiap penanggung jawab usaha dan atau kegitan wajib menyampaikan laporan tentang penaatan persyaratan izin pembuangan air limbah ke air atausumber air. (3) Laporan sebagaimana dimaksud dalam ayat (1) dan ayat (2) wajib disampaikan sekurangkurangnya sekali dalam 3 (tiga) bulan kepadaBupati/Walikota dengan tembusan disampaikan kepada Menteri".

Pasal 40 ayat (2) Peraturan Pemerintah Nomor 82 Tahun 2001 tentang Pengelolaan Kualitas Air dan Pengendalian Pencemaran Air, yang menyatakan bahwa:

"Setiap usaha dan atau kegiatan yang akan membuang air limbah ke air atau sumber air wajib mendapat izin tertulis dari Bupati/Walikota".

Pasal 8 ayat (1) dan ayat (2), Peraturan Menteri Lingkungan Hidup Nomor Nomor 06 tahun 2006 tentang Baku Mutu Air Limbah Bagi Usaha dan/atau Kegiatan Pertambangan bijih Nikel menyatakan bahwa :

“(1) Penanggung jawab usaha dan/atau kegiatan pertambangan bijih nikel wajib melakukan kajian lokasi titik penaatan air limbah dari usaha dan/atau kegiatan pertambangan bijih nikel. (2) Lokasi titik penaatan sebagaimana dimaksud pada ayat (1) harus berada pada saluran air limbah yang : a. keluar dari sistem pengolahan air limpasan (run off) sebelum dibuang ke badan air dan sengaja tidak terkena pengaruh dari kegiatan lain dan/atau sumber lain selain dari kegiatan penambangan bijih nikel; dan atau b. keluar dari sistem pengolahan air limbah dari proses pengolahan bijih nikel sebelum dibuang ke badan air dan sengaja tidak terkena pengaruh dari kegiatan lain dan/atau sumber air lain selain dari kegiatan pengolahan bijih nikel.

b. Tidak terdapat saluran drainase yang menampung oli bekas dari oil trap.

Berdasarkan hal tersebut telah melanggar:

Pasal 67 Undang-undang Nomor 32 Tahun 2009 tentang Perlindungan dan Pengelolaan Lingkungan Hidup, yang menyatakan bahwa:

"Setiap orang berkewajiban memelihara kelestarian fungsi lingkungan hidup serta mengendalikan pencemaran dan/atau kerusakan lingkungan hidup".

Pasal 37 Peraturan Pemerintah Nomor 82 Tahun 2001 tentang Pengelolaan Kualitas Air dan Pengendalian Pencemaran Air, yang menyatakan bahwa:

"Setiap penanggung jawab usaha dan atau kegiatan yang membuang air limbah ke air atau sumber air wajib mencegah dan menanggulangi terjadinya pencemaran air".

c. Tidak melakukan pengukuran kualitas emisi pada genset sehingga tidak melakukan perhitungan beban pencemaran.

Berdasarkan hal tersebut telah melanggar:

Pasal 68 huruf c Undang-undang Nomor 32 Tahun 2009 tentang Perlindungan dan Pengelolaan Lingkungan Hidup yang menyatakan bahwa:

"Setiap orang yang melakukan usaha dan/atau kegiatan berkewajiban: (c) menaati ketentuan tentang baku mutu lingkungan hidup dan/atau kriteria baku kerusakan lingkungan hidup".

Pasal 21 huruf a dan b Peraturan Pemerintah Nomor 41 Tahun 1999 tentang Pengendalian 
Pencemaran Udara, yang menyatakan bahwa:

"Setiap orang yang melakukan usaha dan/atau kegiatan yang mengeluarkan emisi dan/atau baku tingkatgangguan ke udara ambien wajib: a. menaati baku mutu udara ambien, baku mutu emisi, dan baku tingkat gangguan yang ditetapkan untuk usaha dan/atau kegiatan yang dilakukannya; $b$. Melakukan pencegahan dan/atau penanggulangan pencemaran udara yang diakibatkan oleh usaha dan/atau kegiatan yang dilakukannya”.

d. Label pada kemasan limbah B3 tidak dilengkapi dengan informasi limbah B3

Berdasarkan hal tersebut telah melanggar:

Pasal 19 ayat (2) dan (3) Peraturan Pemerintah Nomor 101 Tahun 2014 tentang Pengelolaan Limbah Bahan Berbahaya dan Beracun, yang menytakan bahwa:

"(2) Kemasan Limbah B3 sebagaimana dimaksud pada ayat (1) wajib dilekati Label Limbah B3 dan Simbol Limbah B3. (3) Label Limbah B3 paling sedikit memuat keterangan mengenai: a. nama Limbah B3; b. identitas Penghasil Limbah B3; c. tanggal dihasilkannya Limbah B3; dan d. tanggal Pengemasan Limbah B3”.

Pasal 2 ayat (5) Peraturan Menteri Lingkungan Hidup Nomor 14 Tahun 2013 tentang Simbol dan Label Limbah Bahan Berbahaya dan Beracun, yang menyatakan bahwa:

"(5) Pelabelan Limbah B3 sebagaimana dimaksud pada ayat (4) dilakukan sesuai informasi penghasil, alamat penghasil, waktu pengemasan, jumlah, dan karakteristik Limbah B3”.

e. Tidak semua limbah B3 yang dihasilkan disimpan pada gudang penyimpanan limbah B3

Berdasarkan hal tersebut telah melanggar:

Pasal 12 ayat (1) Peraturan Pemerintah Nomor 101 Tahun 2014 tentang Pengelolaan Limbah

Bahan Berbahaya dan Beracun, yang menyatakan bahwa:

"Setiap Orang yang menghasilkan Limbah B3 wajib melakukan Penyimpanan Limbah B3".

Pasal 25 ayat (1) huruf b Peraturan Pemerintah Nomor 101 Tahun 2014 tentang Pengelolaan Limbah Bahan Berbahaya dan Beracun, yang menyatakan bahwa:

"Persyaratan lingkungan hidup sebagaimana dimaksud dalam Pasal 24 huruf d paling sedikit meliputi: $b$. Menyimpan Limbah B3 yang dihasilkan ke dalam tempat penyimpanan limbah B3".

\section{B. KESIMPULAN}

Berdasarkan analisis yuridis yang telah dilakukan, maka dapat disimpulkan bahwa:

1. Perusahaan tambang bijih nikel tersebut telah melakukan pelanggaran pada:

- Undang-undang Nomor 32 Tahun 2009 tentang Perlindungan dan Pengelolaan Lingkungan Hidup pada Pasal 20 ayat (3) huruf b, Pasal 67, Pasal 68 huruf c;

- Peraturan Pemerintah Nomor 82 Tahun 2001 tentang Pengelolaan Kualitas Air dan Pengendalian Pencemaran Air pada Pasal 34 ayat (2) dan (3), Pasal 37, Pasal 40 ayat (2);

- Peraturan Pemerintah Nomor 41 Tahun 1999 tentang Pengendalian Pencemaran Udara pada Pasal 21 huruf a dan b;

- Peraturan Pemerintah Nomor 101 Tahun 2014 tentang Pengelolaan Limbah Bahan Berbahaya dan Beracun pada Pasal 12 ayat (1), Pasal 25 ayat (1) huruf b;

- Peraturan Menteri Lingkungan Hidup Nomor 14 Tahun 2013 tentang Simbol dan Label Limbah Bahan Berbahaya dan Beracun pada Pasal 2 ayat (5); dan

- Peraturan Menteri Lingkungan Hidup Nomor 06 tahun 2006 tentang Baku Mutu Air Limbah Bagi Usaha dan/atau Kegiatan Pertambangan bijih Nikel pada Pasal 8 ayat (1) dan (2).

2. Berdasarkan analisis yuridis yang telah dilakukan, maka dapat disimpulkan bahwa perusahaan tambang bijih nikel tersebut Tidak Taat 


\section{UCAPAN TERIMAKASIH}

Terimakasih kepada Kepala Balai Pengamanan dan Penegakan Hukum Lingkungan Hidup dan Kehutanan Wilayah Sulawesi, Bapak Dodi Kurniawan, S.Pt, M.H., Kepala Seksi I Makassar, Bapak Muhammad Amin, S.H., serta penghargaan yang sebesar-besarnya kepada mentor saya, Bapak Achmad Yusuf Arief, S.H., M.H. yang telah memberikan sumbangsih saran dalam menyelesaikan makalah ini.

\section{DAFTAR PUSTAKA}

Arif, Irwandy, (2018), Nikel Indonesia, Gramedia Pustaka Utama, Jakarta. 5 - 10.

Keputusan Kepala Badan Pengendalian Lingkungan Nomor 01 tahun 1995 tentang Tata Cara dan Persyaratan Teknis Penyimpanan dan Pengumpulan Limbah Bahan Berbahaya dan Beracun. (1995). Jakarta. 31 - 54.

Keputusan Kepala Badan Pengendalian Lingkungan Nomor 205 Tahun 1996 tentang Pedoman Teknis Pengendalian Pencemaran Udara Sumber Tidak Bergerak. (1996). Jakarta. 1612 - 1720.

Keputusan Menteri Lingkungan Hidup Nomor 49 Tahun 1996 tentang Baku Tingkat Getaran. (1996). Jakarta. 2 - 12 .

Peraturan Menteri Lingkungan Hidup Nomor 04 Tahun 2009 tentang Ambang Batas Emisi Gas Buang Kendaraan Bermotor Tipe Baru. (2009). Jakarta. 2 - 81.

Peraturan Menteri Lingkungan Hidup Nomor 04 Tahun 2014 tentang Baku Mutu Emisi Sumber Tidak Bergerak bagi Usaha dan/atau Kegiatan Pertambangan. (2014). Jakarta. 2 - 35.

Peraturan Menteri Lingkungan Hidup Nomor 09 tahun 2006 tentang Baku Mutu Air Limbah Bagi Usaha dan/atau Kegiatan Pertambangan Bijih Nikel. (2006). Jakarta. 2 - 8.

Peraturan Menteri Lingkungan Hidup Nomor 14 Tahun 2013 tentang Simbol dan Label Limbah Bahan Berbahaya dan Beracun. (2013). Jakarta. 3 - 37.

Peraturan Pemerintah Nomor 41 Tahun 1999 tentang Pengendalian Pencemaran Udara. (1999). Jakarta. $1-18$.

Peraturan Pemerintah Nomor 82 Tahun 2001 tentang Pengelolaan Kualitas Air dan Pengendalian Pencemaran Air. (2001). Jakarta. 2 - 32.

Peraturan Pemerintah Nomor 101 Tahun 2014 tentang Pengelolaan Limbah Bahan Berbahaya dan Beracun. (2014). Jakarta. 2 - 150.

Undang-undang Republik Indonesia Nomor 32 Tahun 2009 tentang Perlindungan dan Pengelolaan Lingkungan Hidup. (2009). Jakarta. 2 - 110.

Undang-undang Republik Indonesia Republik Indonesia Nomor 18 tahun 2008 tentang Pengelolaan Sampah.

(2008).

Jakarta.

2

37. 